Faculdade de Ciências Econômicas da UFRGS
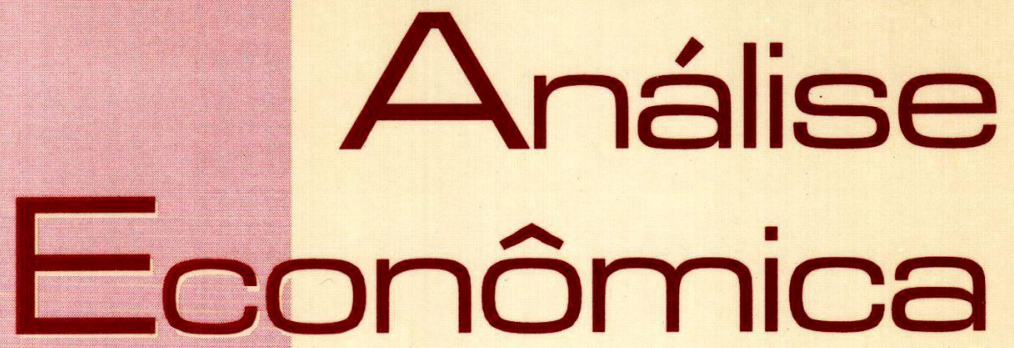

A Instabilidade Financeira dos Anos 90: Alqumas ImplicaçÕEs para as Economias Capitalistas Periféricas André Cunha e Daniela Prates

A Ampliação Recente da Participação Estrangeira no Sistema Bancário Brasileiro Maria Cristina Penido de Freitas

Infra-estrutura de Informações e Sistema Nacional de InOvação

Eduardo da Motta e Albuquerque

Custo Social dos Recursos Hídricos em Bacias Hidrográlicas Internacionais: O Caso da Bacia do Paraná Jandir Ferrera de lima e José Carrera-Fernandez

Preferência pela liọuidez e Escollha de Porrtólio

José Luis Oreiro

Eficiência, Objetivo e Coordenaçĩo da Política Macroeconômica no Período: 1974 - 1979

JoÃo Sicsú

Macroeconomia Moderna: Keynes e a ECONOMIA CONTEMPORÂNEA - RESENha

Simone Silva de Deos
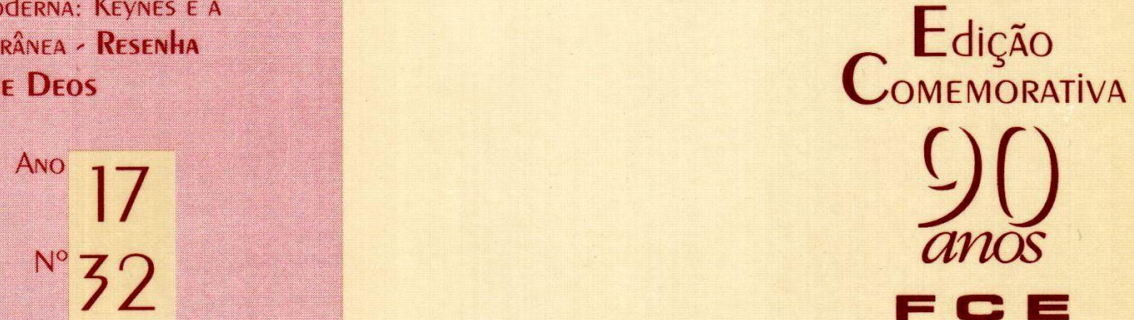

Setembro, 1999 
Universidade Federal do Rio Grande do Sul

Reitora: Proft. Wrana Maria Panizzi

Faculdade de Ciências Econômicas

Diretora: Prof ${ }^{a}$. Otilia Beatriz Kroeff Carrion

Centro de Estudos e Pesquisas Econômicas

Diretor: Prof. Fernando Ferrari Filho

Departamento de Ciencias Econômicas

Chefe: Prof Luiz Alberto Oliveira Ribeiro de Miranda

Curso de Pós-Graduação em Economia

Coordenador: Prof. Marcelo Savino Portugal

Curso de Pós-Graduaçāo em Economia Rural

Coordenador: Prof. Carlos Guilherme A. Mielitz Netto

Conselho edtrorial

Achyles B. Costa, Aray M. Feldens, Carlos A. Crusius, Carlos G. A. Mielitz Netto, Eduardo A. Maldonado Filho, Eduardo P. Ribeiro, Eugênio Lagemann, Fernando Ferrari Filho, Gentil Corazza, Marcelo S. Portugal, Nali J. Souza, Otilia B. K. Carrion, Paulo A. Spohr, Paulo D. Waquil, Pedro C. D. Fonseca, Roberto C. Moraes, Ronald Otto Hillbrecht, Stefano Florissi, Eleutério F. S. Prado (USP), Fernando H. Barbosa (FGV/RJ), Gustavo Franco (PUC/RJ), João R Sanson (UFSC), Joaquim P. Andrade (UnB), Juan H. Moldau (USP), Paul Davidson (Univ. of Tennessee), Werner Baer (Univ. of Illinois).

Comissão EDITORLAL

Eduardo Augusto Maldonado Filho, Fernando Ferrari Filho, Gentil Corazza, Marcelo Savino Portugal, Paulo Dabdab Waquil; Roberto Camps Moraes.

EDrTor: Gentil Corazza

Edrror Adjunto: Pedro Silveira Bandeira

SeCretaria: Laize Espindula.

REVISÃo DE TEXTos: Vanete Ricacheski.

Fundador: Prof. Antônio Carlos Santos Rosa

Os materiais publicados na revista Análise Econômica são da exclusiva responsabilidade dos autores. É permitida a reprodução total ou parcial dos trabalhos, desde que seja citada a fonte. Aceita-se permuta com revistas congêneres. Aceitam-se, também, livros para divulgação, elaboração de resenhas e recensões. Toda correspondência, material para publicação (vide normas na terceira capa), assinaturas e permutas devem ser dirigidos ao seguinte destinatário:

Prof, Gentul Corazza

Revista Análise Econômica - Av. João Pessoa, 52 CEP 90040-000 PORTO ALEGRE - RS, BRASIL

Telefones: 0xx (51) 316-3348 e 316-3440 - Fax: 0xx (51) 316-3990 rae@vortex.ufrgs.br

Análise Econômica

Ano 17, n. 32, setembro, 1999 - Porto Alegre

Faculdade de Ciências Econômicas, UFRGS, 1999

Periodicidade semestral, março e setembro.

ISSN 0102-9924

1. Teoria Econômica - Desenvolvimento Regional -

Economia Agrícola - Pesquisa Teórica e Aplicada -

Periódicos. I. Brasil.

Faculdade de Ciências Econômicas,

Universidade Federal do Rio Grande do Sul.

CDD 330.05

CDU 33 (81) (05) 


\title{
A instabilidade financeira nos anos 90: Algumas implicações para as economias capitalistas periféricas
}

\author{
André Moreira Cunha \\ e Daniela Magalhães Prates *
}

\begin{abstract}
Sinopse :Nos últimos anos, os esforços de liberalização e de maior integração econômica, especialmente em sua dimensão financeira, têm sido acompanhados por crises frequientes. Este artigo pretende explorar como o mainstream da economia tem percebido esta instabilidade. Em seguida, argumenta-se que sua visão é limitada, gerando, do ponto de vista do desenvolvimento econômico, uma agenda restritiva para as economias periféricas.
\end{abstract}

Palavras-chave: globalização; fluxos de capitais; crises financeiras; países em desenvolvimento.

\begin{abstract}
In the last years, the trend of global integration and liberalization, mainly at the financial side, has been accompanied by an increasing frequency of financial crises, in both the developed and devoloping countries. The aim of this article is to compare two different views of this crises - the mainstream and an alternative view, based on the ideas of Keynes and Minsky - and to show how the first interpretation imply in a limited agenda for the developing countries.
\end{abstract}

Key words: globalization; capital flows; financial crises; developing countries.

\section{Introdução}

A década de 90 tem-se caracterizado por uma aceleração do processo de integração produtiva e financeira, motivada por dois conjuntos de determinantes: (i) econômicos, derivados da disseminação das novas tecnologias de base microeletrônica e das inovações financeiras; (ii) e políticos, a partir do reordenamento das relações de poder no plano internacional, com a reafirmação da hegemonia americana (1979-82), com o fim da Guerra Fria e a formação de blocos regionais como a União Européia, o Nafta e o Mercosul. O termo

\footnotetext{
Professor da Unisinos e Doutorando pelo Instituto de Economia/UNICAMP (amcunha@mercado.unisinos.tche.br); Pesquisadora do FUNDAP- DIESP, Professora da Universidade Paulistá (Unip) e Doutoranda pelo Instituto de Economia/UNICAMP (dprates@fundap.sp.gov.br). Trabalho selecionado para o IV Encontro Nacional de Economia Política - Porto Alegre, 1 a 4 de junho de 1999. Os autores agradecem os comentários de Marcos Antônio Macedo Cintra, eximindo-o das incorreções que porventura persistirem. Versão: março de 1999.
} 
globalização tem sido utilizado para definir essas transformações, entendidas por muitos como definidoras de uma nova etapa de desenvolvimento do capitalismo. Ainda que haja uma significativa polêmica em torno das suas características e do ineditismo, é rażoável afirmar que, do ponto de vista dos países capitalistas periféricos, tem-se verificado um predomínio de políticas que procuram garantir uma maior inserção nos fluxos globais de mercadorias e dinheiro. Assim, desde o final dos anos 80, assistiu-se a movimentos generalizados de liberalização dos mercados e convergência para parâmetros institucionais mais liberais. Estabeleceu-se um consenso em torno da idéia de limitação da atuação política dos Estados Nacionais sobre os mercados competitivos. Este é um fato importante, na medida em que o período de modernização destas economias, entre o pós Segunda Guerra Mundial e meados dos anos 70 , foi marcado pelo predomínio da visão de que a política teria um papel central na aceleração do desenvolvimento econômico e social.

A visão mais otimista e de defesa da liberalização dos mercados, manifesta na opiniões dos representantes do mainstream da Economia e nas proposições de política dos órgãos multilaterais, como o Banco Mundial e o FMI, tem sido posta em xeque pela crescente instabilidade econômica que caracterizou a economia internacional nas últimas décadas. Mais especificamente: os esforços de liberalização e de maior integração econômica, especialmente em sua dimensão financeira, têm sido acompanhados por crises frequientes e de escopo cada vez maior, que têm ultrapassado os países e regiões inicialmente afetados. Isto tanto nas economias periféricas como nas industrializadas. Com isso, têm-se criado profundas contradições naquela defesa, pois: (i) não se pode negar a forte instabilidade oriunda dos mercados financeiros liberalizados; (ii) cujos impactos têm sido sentidos em economias com distintos arcabouços institucionais e desempenho econômico.

Pretende-se explorar essas contradições a partir de uma revisão não extensiva da literatura recente sobre crises financeiras. Argumenta-se que, do ponto de vista do desenvolvimento econômico, a visão convencional ${ }^{1}$ sobre a instabilidade financeira gera uma agenda reducionista para as economias capitalistas de forma geral e, particularmente, para as periféricas. Dividir-se-á o trabalho da seguinte forma: (i) procurar-se-á identificar como a literatura convencional tem procurado explicar a crescente instabilidade financeira, contrapondo esta visão com a tradição keynesiana expressa nos trabalhos de Minsky; (ii) para então, à guisa de conclusão, mapear as dificuldades estruturais encontradas pelas economias periféricas em ampliar seus graus de liberdade na condução do processo de desenvolvimento econômico.

\footnotetext{
${ }^{1}$ Ao longo do texto os termos convencional, neoclássica ou mainstream, são tratados como sinônimos. As divergências entre as suas distintas correntes serão pontuadas quando necessário.
} 


\section{Instabilidade financeira: imperfeições dos mercados ou característica estrutural das economias capitalistas?}

Uma característica central da literatura do mainstream é considerar como pressuposto, explícito ou implícito, a idéia de que os mercados competitivos ou livres são eficientes no processo de alocação de recursos. Como não poderia deixar de ser, essa visão se aplica ao sistema financeiro. Nesse caso, supõe-se que agentes econômicos perfeitamente racionais também são eficientes na identificação dos sinais de preços emitidos pelos mercados e na aplicação dos seus recursos. Se o sistema financeiro é entendido como o locus de intermediação de recursos entre agentes deficitários - mas dispostos a se endividar para realizar investimentos que apresentem uma taxa de retorno positiva - e agentes superavitários, uma crise de natureza financeira significa o rompimento dos fluxos de recursos entre estes dois conjuntos de agentes. Sua origem costuma ser buscada em fragilidades nos fundamentos econômicos - moeda e fisco - e/ou nas instituições. Invariavelmente, tem-se um impacto negativo sobre o nível de atividade da economia ${ }^{2}$. Assim, ainda que se admita a idéia de que as crises financeiras fazem parte do mundo real, e de que elas são recorrentes ${ }^{3}$, não se trabalha com a noção de que as economias capitalistas são inerentemente instáveis. Essa perspectiva, mais próxima da tradição keynesiana (KEYNES, 1936), expressa na hipótese de instabilidade financeira de Minsky (1991), será trabalhada após uma síntese das contribuições mais recentes da literatura convencional sobre crises financeiras.

\subsection{A perspectiva convencional}

Krugman (1997) sugere a existência de duas famílias de modelos canônicos de crises cambiais. A primeira associa os ataques especulativos

\footnotetext{
2 "Uma economia saudável e vibrante requer um sistema financeiro que desloque fundos para agentes econômicos que possuam as oportunidades de investimentos mais produtivas.... As crises financeiras interferem com esse processo porque podem direcionar a economia de um equilíbrio com produção elevada e na qual os mercados financeiros tenham um bom desempenho, para uma posição em que a produção decline agudamente porque o sistema financeiro é incapaz de canalizar fundos para aqueles com as melhores oportunidades de investimento" (MISHKIN, 1992, p. 115). Esta e as demais traduções são dos autores.

3 "Crises financeiras não são únicas dos sistemas financeiros correntes, é claro; a história está repleta de crises bancárias e cambiais" (IMF, 1998a, p. 110). Para um exame da evolução do sistema financeiro internacional e suas várias crises, ver Eichengreen (1996). Em Kindleberger (1978), encontramos uma descrição detalhada de vários episódios de crise financeira. Sua perspectiva ressalta os aspectos irracionais e miméticos no comportarnento dos agentes econômicos (as manias especulativas, seguidas de reversões de expectativas, pânicos e rupturas) bem como a natureza intrinsecamente instável das economias capitalistas, e não causa grandes simpatias nos autores convencionais. Por exemplo, Krugman (1991) coloca-o em um plano inferior - junto com Minsky - na hierarquia das teorias que explicam as crises financeiras.
} 
à reversão de expectativas dos agentes com relação à capacidade da Autoridade Monetária (A.M.) sustentar seu compromisso com certa paridade cambial pela venda irrestrita de reservas. A existência de desequilíbrio fiscais motivaria os agentes a antecipar futuras expansões monetárias, gerando uma fuga em direção às moedas estrangeiras até o momento em que a A.M. não fosse mais capaz de sustentar a paridade. Assim, desvalorizase a moeda local, no bojo da fuga de capitais. Esta família de modelos, iniciados por Krugman (1979), teria tido um forte apelo explicativo nas crises cambiais latinas no final dos anos 70 , início dos 80 . A sugestão de política que emerge passa pela manutenção de fundamentals equilibrados, a partir da austeridade fiscal. Para a racionalização ex-post da crise do Sistema Monetário Europeu, surge uma segunda geração de modelos (OBSTFELD, 1996). Complexificam-se os mecanismos de formação das expectativas associados aos ataques especulativos. Ao lado da compra e venda de divisas, a A.M. utiliza a taxa de juros para atingir as metas cambiais e regular o nível de reservas. Porém, com isso, estabelece-se um trade off: o aumento da taxa de juros para sustentar a meta cambial impõe um custo recessivo sobre o nível de emprego. Assim, os investidores deixam de olhar somente para as contas fiscais e passam a formar suas expectativas também em função da percepção de qual seria o limite aceitável de comprometimento do emprego para sustentar-se a paridade cambial. Se apostarem na insustentabilidade do arranjo câmbio-juros, antecipam uma futura desvalorização, fugindo para ativos denominados em divisas. Portanto os investidores exploram o dilema das A.M.s: garantir a confiabilidade da moeda local pela sustentação da paridade, mesmo que isso exija aumentos recorrentes e significativos da taxa de juros versus o custo recessivo da política monetária restritiva. Assim, nos modelos de segunda geração pode haver crise cambial mesmo sem a presença de desequilíbrios fiscais significativos.

A crise asiática de 1997 gerou um questionamento em relação ao poder explicativo dos modelos anteriores (KRUGMAN, 1998). Sem desequilíbrios fiscais significativos e com níveis elevados de crescimento e emprego, comprometer-se-ia os mecanismos de formação de expectativas dos modelos convencionais (CUNHA, 1998; ver tabelas 1 e 2). Mais do que isso, logo se percebeu que a crise cambial era uma decorrência da crise nos mercados de capitais. Certos elementos passaram a ser enfatizados no front explicativo da dinâmica de expansão e crise: o papel do moral hazard associado à crença dos agentes de que haveria a sustentação de suas posições a descoberto por parte dos governos, o efeito-contágio, a fragilidade regulatória dos sistemas financeiros etc. Corsetti et alii (1998) argumentam que a crise asiática está propici- 
ando o surgimento de uma terceira geração de modelos de crise. Em seu próprio modelo, os autores procuram resgatar a raiz fiscal da crise. Assim, mesmo que não houvesse nenhum desequilíbrio corrente nas contas públicas, na presença de governos que acenassem para o socorro a agentes privados com problemas patrimoniais, existiria uma espécie de "déficit fiscal escondido", antecipado pelo agentes quando dos ataques especulativos ${ }^{4}$. Consegue-se uma forma sofisticada de recolocar o Estado como o responsável pela crise. Porém, aqui pesariam mais os desajustes institucionais, derivados da ineficiência da regulação do sistema financeiro em conjunto com um padrão espúrio de relações entre Estado e Mercado ${ }^{5}$.

A associação entre mecanismos de regulação ineficientes e crises financeiras é enfatizada por Mishkin (1992, 1994 e 1998), que pretende construir uma teoria geral das crises financeiras fundada na teoria da informação assimétrica ${ }^{6}$. Para esse autor, a eficiência alocativa do sistema financeiro passa a ser comprometida quando há assimetria de informações, ou seja, "....uma situação na qual uma das partes do contrato financeiro tem informações muito menos precisas do que a outra parte." (MISHKIN, 1998, p. 2). Isto geraria dois tipos fundamentais de problemas: (i) a seleção adversa, que ocorre antes da transação, e significa que, normalmente, os agentes mais disposto a procurar empréstimos são os que tendem a ter um maior risco de crédito; (ii) e o moral hazard, que emerge toda a vez que o tomador de çrédito sente-se incentivado a investir em projetos de risco elevado, nos quais o sucesso implica um forte retorno para si, e o fracasso uma perda elevada - e desproporcional

\footnotetext{
4 "Especificamente, na raiz do nosso modelo está a consideração de que intervenções de socorro podem tomar diferentes formas, mas em última instância têm uma natureza fiscal e afetam diretamente a distribuição de renda e riqueza; um sistema implícito de socorro assegurado é equivalente a um estoque contingente de passivo público que não está refletido na dívida e nas contas de déficit até a crise ocorrer. Esses passivos podem ser manejados na presença de choques específicos a firmas ou mesmo choques setoriais suaves. Eles se tornam preocupantes na presença de choques macroeconômicos de tamanho considerável....que revelem inteiramente a fragilidade financeira associada a excessivos investimentos e tomada de risco. Enquanto os déficits fiscais antes da crise eram baixos, a fiança implícita ou explícita representa um sério peso no equilíbrio fiscal futuro, um peso cuja magnitude nos paŕses asiáticos tem sido estimada ao redor de 10/20\% do PIB. Uma crise financeira e cambial pode ser entendida como a consequiência da antecipação dos custos de socorro e dos conflitos distributivos em quem sustentar esses custos, que geram a expectativa de uma monetização parcial dos futuros déficits fiscais e de uma queda na atividade econômica induzida pelos ajustes fiscais e externos requeridos."(CORSSETI et al. 1998, p. 6-7)

${ }^{5}$ A perspectiva convencional para a crise asiática está em FMI (1998a e b). Para uma crítica à visão convencional ver Cunha (1998), Wade \& Veneroso (1998), UNCTAD (1998) e Kregel (1998).

"A teoria da informação assimétrica é um dos elementos centrais das "novas teorias da intermediação", desenvolvidas por autores neoclássicos a partir dos anos 70 - por exemplo, Leland \& Peyle (1977), Chan (1983) - e também foi incorporada na literatura novo-keynesiana - ver, Stiglitz \& Weiss (1981). Nessas teorias, a origem das falhas ou imperfeições de mercado estaria na assimetria de informações entre credores e devedores (e também entre acionistas e administradores de empresas) e / ou na inexistência de contratos completos. Os intermediários financeiros seriam os agentes econômicos que surgem como resposta endógena a essas imperfeições. Já na teoria de intermediação financeira de Gurley \& Shaw, dos anos 50, essas falhas decorriam da existência de custos de transação que resultam em economias de escala. Para um survey dessa literatura, ver Ferreira \& Freitas (1995).
} 
ao ganho em caso de sucesso - para o emprestador ${ }^{7}$. A seleção adversa seria um assimetria ex ante (à concessão do crédito) enquanto o risco moral um assimetria ex post. Neste sentido, mostra-se crucial estabelecer instituições e "regras do jogo" que permitam aos tomadores e emprestadores de crédito obter, igualmente, informações de qualidade sobre os riscos e retornos esperados dos seus investimentos, pois ".... minimizar o problema de seleção adversa requer que o emprestador deva separar os bons riscos de crédito dos maus [...] (para) minimizar o problema do moral hazard, os emprestadores devem impor restrições (ajustes restritivos) sobre os tomadores, de modo que estes não se engajem em comportamentos que tornem menos provável que eles possam pagar o empréstimos..." (MISHKIN, 1998, p. 2-3). Além disso, torna-se central a existência de uma "rede de proteção" do sistema, com destaque para a função de emprestador em última instância da A.M, a qual impede que problemas localizados de liquidez gerem crises significativas. Porém sua existência é contraditória na medida em que preserva o sistema e pode, em tese, gerar moral hazard. Para minimizar esse problema há que se fortalecer a regulamentação do sistema como um todo.

Uma vez identificadas as principais assimetrias informacionais, o autor procura mostrar que: "(a) instabilidade financeira ocorre quando os choques no sistema financeiro interferem com os fluxos de informação, de modo que este sistema não consegue mais executar sua função de canalizar fundos para oportunidades de investimento produtivo. Sem acesso a esses fundos, indivíduos e firmas cortam seus gastos, resultando em contração das atividades econômicas, que às vezes pode ser bem severa." (MISHKIN, 1998, p. 8). Mishkin sugere que quatro fatores fundamentais levariam à instabilidade financeira: (i) o aumento da taxa de juros, que estimularia a seleção adversa, na medida em que os investidores com projetos de maior risco seriam exatamente aqueles dispostos a pagar mais pelo crédito - assim, quanto mais elevada a taxa de juros, maior a seleção adversa do crédito, e maior o risco de crescimento na inadimplência; (ii) o aumento da incerteza, que tornaria as informações imprecisas, dificultando a avaliação do risco de crédito e estimulado a seleção adversa $^{8}$; (iii) o efeito da mudança no preço dos ativos sobre os balanços, que ao comprometer o valor dos colaterais dados pelos tomadores de crédito e o valor presente da sua renda líquida, ampliaria o risco de crédito e, assim, a

\footnotetext{
${ }^{7}$ A literatura convencional costuma apontar que a existência de mecanismos governamentais, explícitos ou implícitos, de apoio aos "devedores", tende a criar situações de moral hazard. Este tem sido um forte argumento na explicação de porque os investidores asiáticos tenderam alavancar-se tanto, superestimando o retorno dos investimentos e subestimando riscos (KRUGMAN, 1998, CORSETTI ET ALLI, 1998).

${ }^{8}$ É importante esclarecer que, nesse caso, o termo incerteza deve ser entendido no sentido fraco. Se o autor estivesse se referindo à incerteza no sentido forte - utilizada por Keynes e pelos pós-keynesianos - não poderia falar de informações imprecisas, pois parte das informações simplesmente não existiriam no momento de tomada de decisões.
} 
seleção adversa e o moral hazard ${ }^{9}$; (iv) e as crises bancárias, na medida em que uma das funções centrais dos bancos é produzir informações que facilitam a canalização dos recursos para os investimentos - quando há uma deterioração nos balanços dos bancos, especialmente se motivado pela ampliação dos créditos não pagos, tende-se a uma deterioração na qualidade das informações e do crédito, bem como uma contração deste. Em conjunto, esses fatores tendem a ampliar a instabilidade do sistema, pois estimular-se-ia os agentes carregados de mais risco a tomar crédito (seleção adversa) e/ou a incorrerem em riscos excessivos por possuir informações distintas do emprestador - como, por exemplo, acreditar que não sofrerá perdas por ter algum tipo de apoio estatal. Reforçase a idéia de que a estabilização do sistema financeiro passa pela minimização das assimetrias informacionais. Com uma regulação apropriada, um aumento nos juros e/ou na incerteza, uma queda no preço dos ativos ou problemas bancários localizados, não se converteriam, necessariamente, em crises financeiras.

Mishkin (1996 e 1998) também procura diferenciar os mecanismos de origem e propagação das crises financeiras entre os países desenvolvidos e em desenvolvimento. Assim, nas economias desenvolvidas, com um histórico de inflação moderada, as dívidas são geralmente de longo prazo e denominadas em moeda nacional. Neste contexto, uma queda não antecipada da inflação pode reduzir o valor presente líquido das firmas. Isto porque as taxas de juros tendem a ser fixadas em valores nominais por um longo período, com as taxas reais estimadas a partir de uma certa perspectiva de inflação. Se a inflação efetiva for menor que a esperada, aumenta o peso dos juros reais sobre os passivos. Se não houver uma valorização semelhante nos ativos, o valor real líquido das empresas cai. Assim, uma queda abrupta e não esperada da inflação pode gerar problemas de seleção adversa e moral hazard que, se profundos, poderiam gerar crises financeiras. Ao contrário, a experiência dos países em desenvolvimento é de alta inflação e endividamento de curto prazo, normalmente em moeda estrangeira. Uma queda na inflação não gera o mesmo tipo de efeito no fluxo de caixa das empresas, como nos países desenvolvidos, pois a duração curta dos contratos permite ajustes mais rápidos - a taxa real de juros é permanentemente ajustada às expectativas inflacionárias. Mudanças não antecipadas na taxa de câmbio acabam tendo um efeito semelhante à queda da inflação nos países desenvolvidos. Uma desvalorização cambial tende a

\footnotetext{
${ }^{9}$ Colaterais - como imóveis, ações, títulos de dívida etc. - de boa qualidade minimizam os problemas derivados das assimetrias informacionais, pois garantem ao investidor proteção em caso de default. Porém, quando há uma inflação no preço dos ativos, de modo que o valor nocional destes colaterais esteja muito acima do que poderia ser considerado de "equilíbrio", uma queda súbita daquele poderia precipitar uma crise bancária ou financeira. Da mesma forma, a inflação de ativos, pode gerar um circuito vicioso, onde o endividamento crescente se sustentaria na expectativa de valorização crescente destes colaterais. Krugman (1998) aponta que este círculo vicioso teria ocorrido na Ásia em 1997.
} 
ampliar o endividamento em moeda doméstica das firmas que contraíram passivos em divisas. Se não houver hedge nas receitas operacionais ou outros ativos, tende-se a gerar um efeito negativo nos fluxos de caixa. Do ponto de vista das crises bancárias, Mishkin aponta que a existência de transparência nas informações com respeito à saúde financeira dos bancos, à qualidade da supervisão e à regulação do sistema financeiro como um todo auxiliam na minimização dos problemas de assimetria informacionais que podem levar a pânicos e corridas bancárias. Em geral, os países em desenvolvimento tendem a ter informações e sistemas de controle de menor qualidade, ampliando os riscos de crise.

Os choques negativos sobre os balanços dos bancos podem tomar várias formas. Já foi destacado o papel da ampliação da taxa de juros, da queda no preço dos ativos e de um declínio não antecipado da inflação (no caso dos países desenvolvidos) ou uma desvalorização cambial (nos países em desenvolvimento) na geração de crises. Um risco adicional de choque nos países em desenvolvimento origina-se na baixa diversificação das operações dos seus bancos. A maior parte da sua carteira de empréstimos tende a se direcionar a tomadores locais, muitos deles com suas operações ativas expostas a flutuações nos preços de commodities e do câmbio. Não raramente, são agentes de pequeno e médio porte sem acesso a fontes de financiamento no mercado internacional. Da mesma forma, os bancos tendem a contrair passivos em divisas. Assim, ficam duplamente expostos ao risco cambial: do lado passivo, pela ampliação de sua própria dívida, e do lado ativo, pela inadimplência de devedores fragilizados pelos choques cambiais. Os bancos dos países desenvolvidos tendem a ter carteiras mais diversificadas e menos expostas a mudanças não antecipadas nos preços de ativos e commodities.

Assim como Mishkin, o FMI (IMF, 1998a), motivado pelas crises cambiais do Sistema Monetário Europeu, do México e da Ásia nos anos 90, também procurou elaborar uma síntese da literatura sobre crises financeiras, mas com dois traços distintos: recorreu a verificações empíricas na explicação de sua natureza e origem; e enfatizou um elemento diferenciador das crises atuais com relação às passadas: a maior velocidade do contágio entre a fonte dos distúrbios e a economia internacional. Desenvolveu-se a seguinte tipologia das crises: a categoria mais geral é chamada de "crise econômica ou financeira". Seus quatro subtipos seriam: (i) as crises cambiais, resultantes de ataques especulativos contra o valor externo das moedas que force sua desvalorização ou que obrigue as A.M. a vender reservas e/ou elevar fortemente as taxas de juros para defender a paridade estabelecida; (ii) as crises bancárias, que ocorrem quando há corridas contra as instituições ou quebras que motivem os bancos a suspenderem a convertibilidade dos seus passivos ou quando a ameaça deste tipo de situação leva as A.M. a socorrer o sistema injetando recursos em grande escala; (iii) as crises financeiras 
sistêmicas, que derivam do aprofundamento das crises bancárias, a partir do ponto em que o sistema financeiro mostra-se incapaz de realizar suas funções de intermediação de recursos, afetando gravemente as atividades produtivas ${ }^{10}$; (iv) e as crises de endividamento externo, que ocorrem quando um país torna-se incapaz de honrar seus débitos externos -- soberanos ou privados. Essas crises seriam determinadas por desequilíbrios macroeconômicos e/ou fragilidades institucionais. Quanto maiores estes e menor a credibilidade das políticas de ajuste, maior o risco de rupturas. Assim: "Crises de todos os tipos têm, freqüentemente, origens comuns: o surgimento de desequilíbrios econômicos insustentáveis e desalinhamentos nos preços dos ativos ou das taxas de câmbio, geralmente no contexto de distorções do sistema financeiro e inflexibilidades estruturais. Uma crise pode ser detonada por uma súbita perda de confiança na moeda e no sistema bancário, induzindo a uma repentina correção no preço dos ativos, ou pela ruptura dos fluxos de crédito e financiamento externo que expõe as economias afetadas a fragilidades financeiras. As crises podem envolver uma acentuada queda no preço dos ativos, e comprometimentos nas instituições financeiras e corporações não-financeiras. É claro que nem toda correção de desequilíbrios envolve uma crise. Sua ocorrência ou não dependerá da magnitude dos próprios desequilíbrios, da credibilidade das políticas de correção e do alcance de um "pouso suave", e da solidez do sistema financeiro do país. Em conjunto esses fatores determinam a vulnerabilidade de um país às crises. As crises podem, então, ser consideradas como a consequiência de distúrbios financeiros e econômicos quando as economias sofrem de um alto grau de vulnerabilidade." (IMF, 1998a, p. 111-112). A tipologia sugerida pelo FMI apresenta uma amplitude capaz de abarcar todos os fatos estilizados associados às recentes crises de natureza financeira ${ }^{11}$. Conforme argumentou-se anteriormente, não se explicita a possibilidade da instabilidade financeira ser intrínseca ao modos operandi das economias capitalistas. Pelo contrário, reafirma-se que desequilíbrios nos fundamentals ${ }^{12}$ - preços de ativos e câmbio, déficits fiscais e em conta corrente etc. ${ }^{13}$ - e instituições inadequadas - por serem incapazes de dar transparência e confiança aos sinais de mercado - deter-

\footnotetext{
${ }^{10}$ Este é o conceito de crise financeira que está em Mishkin (1992, 1994 e 1998).

${ }^{11}$ Assim, sugere-se que a crise asiática de 1997 e mexicana (1994-95) apresentariam uma combinação de crise cambial e bancária A crise do Sistema Monetário Europeu seria tipicamente cambial, enquanto a crise dos países nórdicos no início dos anos 90 teria elementos de crise bancária. Crises bancárias teriam ocorrido, também, na Turquia e Venezuela - na década de 90 . Enquanto que os problemas bancários teriam precedido à crise da dívida na Chile e Argentina em 81-82 (MMF, 1998a, p.112).

${ }^{12}$ Para uma análise pormenorizada do impacto destes desequilíbrios, com referência especial à crise asiática de 1997, ver IMF (1998b).

${ }^{13}$ Não se está sugerindo aqui que estes elementos não sejam relevantes na determinação da instabilidade nas economias capitalistas. Entende-se, todavia, que não se pode tratar abstratamente os desequilíbrios nos fundamentals sem discutir-se a natureza intrinsecamente instável das economias capitalistas.
} 
minam as crises. Com isso, políticas voltadas à prevenção dessas crises passam a estar limitadas à busca de metas monetárias e fiscais capazes de equilibrar as contas públicas e externas e os preços dos ativos relevantes, além do fortalecimento das instituições e regras capazes de gerar "solidez no sistema financeiro".

O FMI buscou suas evidências empíricas ${ }^{14}$ enfatizando as crises financeiras no período posterior ao fim do Sistema Bretton Woods. Analisou 53 países $^{15}$, para o período $1975-97$, mapeando 158 episódios de crises cambiais - identificados pela construção de um índice de pressões nos mercados cambiais, que leva em conta as mudanças nas taxas de câmbio e as perdas de reserva e/ou aumento dos juros para amortizar os ataques especulativos - e 54 crises bancárias - identificadas por eventos ex-post como fechamento, estatização e/ou fusões forçadas de instituições, corridas bancárias ou elevados pacotes de auxílio de liquidez pelo governo. Alguns resultados merecem destaque: (i) o número de crises cambiais nos "mercados emergentes" foi duas vezes maior que nos países industrializados; (ii) há uma precedência, mais freqüente, das crises bancárias com relação às cambiais; (iii) os custos de reestruturação financeira e de perda do produto ${ }^{16}$ são elevados, podendo atingir, respectivamente, de 30 a $40 \%$ do PIB (nos casos mais graves) e, em média, $4.25 \%$ da produção; (iv) porém esses custos são muito mais elevados nos "mercados emergentes".

\subsection{Seguindo a trilha de Keynes e Minsky}

Como ressaltado acima, na teoria convencional, desequilíbrios macroeconômicos e/ou falhas/imperfeições de mercado ${ }^{17}$ - como as assimetrias de informação - seriam os fatores responsáveis pela eclosão das crises financeiras. Assim, a prevenção dessas

\footnotetext{
${ }^{14}$ Há uma vasta literatura que busca identificar a natureza das crises financeiras, bem como indicadores que as antecipem. Para uma survey atualizada ver Kaminsky, Lizondo e Reinhart (1998). Demirgüç-kunt \& Detragiache (1998) estudaram 53 países para o período 1980-1995, constatando que a liberalização financeira amplia a possibilidade de ocorrência de crises bancárias, especialmente quando os mecanismos de supervisão do sistema são falhos. Assim, resolve-se a contradição: (i) há instabilidade, não se pode negar, (ii) a liberalização financeira a potencializa, (iii) porém a responsabilidade última recai sobre as instituições inadequadas, especialmente nos "mercados emergentes".

${ }^{15}$ Utilizou-se uma amostra com 22 países industrializados e 31 países em desenvolvimento. EUA e Alemanha foram excluídos da amostra que verificou a natureza das crises cambiais, na medida em que suas moedas servem de referência para os demais países, mas foram mantidos nos estudos sobre crises bancárias (IMF, 1998a, nota 85).

${ }^{16}$ Calculado pela diferença entre a linha de tendência do produto e seu resultado após a crise

${ }^{17}$ É interessante notar que esse recurso teórico contaminou de tal forma o discurso dos economistas, que acabou se convertendo num poderoso instrumento de retórica. Fenômenos econômicos de diversas naturezas, como ciclos de crédito nos mercados financeiros, endividamento externo excessivo, desemprego em massa, passaram a ser atribuídos às falhas no funcionamento dos mercados (financeiros e de trabalho).
} 
crises demandaria a correção daqueles desequilíbrios e a eliminação das falhas nos mercados financeiros mediante o aperfeiçoamento dos mecanismos de supervisão $\mathrm{e}$ regulamentação. Ou seja, a intervenção governamental é necessária para retirar as "impurezas" dos mercados e tomá-los eficientes, como supõe a teoria. Subjacente a esse raciocínio, existe uma determinada visão sobre o papel dos bancos nas economias capitalistas, qual seja, que essas instituições são meros intermediários de recursos entre poupadores e investidores. $O$ ponto de partida de Keynes e de Minsky (e dos póskeynesianos, de forma geral) é totalmente distinto. Para esses autores, a instabilidade financeiraé uma característica intrínseca do capitalismo. As supostas falhas dos mercados financeiros - informações imperfeitas e assimétricas, impossibilidade dos mercados coordenarem decisões interdependentes, comportamento míope dos bancos num contexto de expectativas otimistas, etc. - são, na realidade, aspectos constituintes das economias capitalistas modernas, nas quais predomina a moeda de crédito, emitida pelos bancos ${ }^{18}$.

A teoria da instabilidade financeira de Minsky ${ }^{19}$ representou um avanço em relação à teoria de Keynes ao introduzir na análise da instabilidade das economias capitalistas a evolução das condições de financiamento das empresas (ou seja, a estrutura passiva e os compromissos decorrentes) e o comportamento dos preços dos ativos financeiros em relação ao preço da produção corrente ao longo do ciclo econômico. Para Minsky, situações de fragilidade financeira são inerentes aos ciclos econômicos do capitalismo e as crises financeiras constituem um componente essencial da fase descendente desses ciclos, os quais são sustentados pela expansão do crédito pelos bancos. Essas instituições, enquanto agentes capitalistas impulsionados pela busca de lucros, tendem a expandir os empréstimos sem uma avaliação adequada dos riscos num contexto de expectativas otimistas e/ou de crescimento econômico, sancionando a demanda de crédito das empresas e das famílias. No auge do ciclo, a tentativa das autoridades monetárias de conterem a expansão creditícia é em geral ineficaz, pois os bancos buscam burlar, permanentemente, as restrições impostas mediante as inovações financeiras. Além disso, a elevação do preço dos ativos financeiros em relação aos ativos instrumentais estimula ainda mais a demanda de crédito, que se mantém elevada enquanto as expectativas são favoráveis. Apenas quando ocorre a reversão cíclica - devido às mudanças adversas nas condições macroeconômicas e/ou à reversão daquelas expectativas - a fragilidade financeira se explicita. Nesse contexto, as famílias e empre-

\footnotetext{
${ }^{18}$ Além de identificarem aspectos constituintes das economias capitalistas como falhas de mercado, autores novo-keynesianos passaram a apresentar algumas idéias de Keynes como se fossem formulações teóricas inovadoras. Como destaca Freitas (1998, p. 77), "esses são os casos, por exemplo, da teoria do racionamento do crédito associada a Stiglitz \& Weiss (1981) e da hipótese da miopia ao desastre ou miopia intrínseca formulada por Guttentag \& Hering $(1984 ; 1986)$ "

${ }^{19}$ Para uma sintese das idéias principais e referências relevantes, elaborada pelo próprio autor, ver Minsky (1991)
} 
sas procuram liquidar seus ativos na tentativa de saldar suas dívidas e os bancos restringem o crédito, diante do aumento dos riscos de inadimplência e da redução do valor dos colaterais. Segundo Minsky, a recessão não se converte num processo deflacionário cumulativo somente se houver uma ação ativa do governo como emprestador de última instância, mediante a intervenção do banco central, e como fonte autônoma de demanda agregada, através da expansão do gasto público.

A teoria de Minsky, apresentada resumidamente acima, oferece os elementos básicos para a compreensão das crises financeiras recentes. No entanto, essa análise centrou-se no ciclo financeiro de uma economia desenvolvida (os EUA) em um contexto de restrição à mobilidade de capitais (sistema de Bretton-Woods), ou seja, com sistemas bancários isolados do mercado financeiro internacional. Assim, para ser utilizada na análise das crises financeiras das economias capitalistas no período recente, essa teoria precisa ser adaptada no sentido de incorporar as transformações financeiras em curso desde a adoção do sistema de taxas de câmbio flutuantes após o colapso de Bretton Woods. No caso das crises financeiras das economias periféricas, essa adaptação também exige a consideração de especificidades dessas economias, como a dependência de fontes de financiamento externas e a ausência de moedas conversíveis.

As décadas de 80 e 90 foram marcadas por profundas transformações no mercado financeiro internacional e nas estruturas financeiras dos países centrais, entre as quais destacam-se a globalização financeira - que compreende o processo de liberalização e/ou desregulamentação financeira doméstica ${ }^{20}$ - a securitização das dívidas, a proliferação de novos instrumentos financeiros e a institucionalização das poupanças financeiras ${ }^{21}$. Essas transformações, que implicaram a supremacia da "economia de ativos" e o crescimento surpreendente das finanças internacionais, alteraram profundamente a natureza dos ciclos econômicos e, conseqüentemente, das crises financeiras. Como mostrou Aglietta (1995), os ciclos econômicos passaram a ser determinados pela evolução dos preços dos ativos financeiros, e não mais pela dinâmica dos investimentos produtivos e pela evolução dos preços dos ativos instrumentais. Na mesma linha de argumentação desse autor, Freitas (1997a) destaca que as inovações financeiras associadas à administração dos passivos e à securitização dos mercados de crédito no contexto de liberalização financeira dos anos 80 reforçaram os movimentos especulativos do tipo "asset price inflation" que provocam crises financeiras independentemente das fases do ciclo econômico ${ }^{22}$. Assim, a hipótese de Minsky - de subordinação dos mercados de

\footnotetext{
${ }^{20}$ A globalização financeira é um pocesso que compreende a eliminação da segmentação dos diferentes mercados financeiros locais. A interpretação dos mercados monetários e financeiros nacionais e sua integração nos mercados mundializados (CHESNAIS, 1996).

${ }^{21}$ Sobre essas transformações ver Chesnais (1996), Freitas (1997a) e Aglieta (1995).

${ }^{22}$ Freitas (1997a) realiza uma análise minuciosa do processo de liberalização financeira nos países centrais e do processo de inflação de ativos nos anos 80 , enfatizando o papel central desempenhado pela concorrência bancária na emergência das siruações de instabilidade financeira. Ver também Freitas (1997b).
} 
ativos financeiros aos mercados de ativos produtivos e de crédito - não é mais válida (Bastos, 1996). Uma manifestação desse processo é a hipertrofia da esfera financeira relativamente à esfera real (produção, investimento, emprego, crescimento) na maioria dos países centrais a partir dos anos 80 , evidenciada pela elevação das seguintes relações: entre os fluxos de receitas dos agentes não-financeiros (famílias e empresas) e o PIB; entre o patrimônio financeiro dos agentes não-financeiros e o PIB, e; entre o patrimônio financeiro e o patrimônio total dos agentes não-financeiros (Boissieu, 1994 e Aglietta, 1995).

No ciclo econômico dominado pela dinâmica financeira, a emergência de situações de fragilidade financeira está associada a boons especulativos nos mercados de ativos financeiros, alimentados pela expansão do crédito bancário num ritmo superior ao da produção. Da mesma forma que no ciclo minskiano, esta fragilidade permanece dissimulada na fase ascendente do ciclo, enquanto a valorização do preço dos ativos se mantém. A inflação de ativos, por sua vez, estimula ainda mais o endividamento dos agentes, devido ao efeito-riqueza. Essa trajetória de elevação do preço dos ativos e do crédito é insustentável no longo prazo. Mas o momento de reversão do ciclo financeiro é desconhecido a priori. A reversão é provocada por um acontecimento súbito e inesperado - como um aumento da taxa de juros - que resulta na deflação do preço dos ativos, seguida pela contração do crédito. A recessão induzida pelas finanças também possui características peculiares. As famílias não desempenham o papel estabilizador observado nas recessões precedentes. Pelo contrário, reforçam a fase descendente do ciclo. Diante da restrição financeira provocada pela queda do preço dos ativos e pelo aumento do serviço das dívidas num contexto de taxas de juros reais elevadas, as famílias procuram aumentar sua poupança financeira - e, assim, reduzem o consumo como forma de compensar a queda da riqueza financeira ${ }^{23}$. Além disso, o corte dos investimentos produtivos do setor privado - com o objetivo de elevar a taxa de autofinanciamento - não é mais contrabalançado pelo aumento do gasto público.

A recorrência de crises financeiras e bolhas especulativas - nas bolsas de valores, nos mercados imobiliários e de securities - é um fenômeno característico do sistema globalizado de finanças liberalizadas, no qual os choques são facilmente transmissíveis através das fronteiras - e, assim, manifestam-se nos mercados cambiais - e de um mercado a outro - mercados de capitais e de crédito - resultando em fortes flutuações nos preços dos ativos e das taxas de câmbio. Como destaca a Unctad (1998), a crise asiática constitui mais uma manifestação da instabilidade financeira sistêmica que tem caracterizado o sistema financeiro internacional desde

\footnotetext{
${ }^{23}$ Numa recessão econômica padrão, a poupança das famílias se comporta de forma contra-cíclica. Diante de uma queda da demanda efetiva que reduz sua receita, esses agentes reduzem sua poupança financeira com o objetivo de preservar o nível de gastos correntes.
} 
o colapso do sistema de Bretton Woods. Contudo, enquanto nos países centrais crises financeiras internas não se transformam em crises cambiais, e vice-versa (por exemplo, a crise das savings \& loans nos EUA e a crise do Sistema Monetário Europeu em 1992, respectivamente), no caso das economias periféricas, as crises financeiras domésticas (crises bancárias ou do tipo asset-price deflation) tendem a se converter em crises cambiais, da mesma forma que essas últimas ameaçam a estabilidade dos sistemas financeiros domésticos. Dessa forma, para a compreensão das crises financeiras recentes dessas economias, é necessário incorporar novos elementos na análise, mais especificamente, os fatores responsáveis pela existência desse feed-back entre crises cambiais e financeiras internas.

Kregel (1998a) avança nessa direção ao analisar a crise das economias asiáticas deflagrada em 1997. Na interpretação desse autor ${ }^{24}$, essa crise foi uma crise financeira, seguida por um processo de debt-deflation, que pode ser explicada nos termos da hipótese de fragilidade financeira de Minsky, aplicada a economias abertas e periféricas num ambiente de livre mobilidade de capitais. O ciclo de crédito que precedeu as crises nos países asiáticos (principalmente, Tailândia e Coréia) foi alavancado pelo ingresso de fluxos de capitais externos, predominantemente de curto $\operatorname{prazo}^{25}$. O aumento desses fluxos para a região a partir de 1993-94 esteve associado à busca de novas oportunidades de negócios pelos bancos internacionais (empréstimos bancários e/ou montagem de operações estruturadas) e pelos investidores institucionais, diante das baixas taxas de retorno nos países de origem, e à crise do México no final de 1994. Do lado da demanda, o contexto de taxas de câmbio estáveis e valorizadas e taxas de juros domésticas elevadas $^{26}$, favoreceu a absorção de recursos externos, seja diretamente pelas empresas, seja pelos próprios bancos domésticos, que os reciclaram internamente mediante empréstimos para empresas, créditos imobiliários e investimentos nas bolsas de valores. O ciclo creditício resultou num aumento excessivo do investimento produtivo e, principalmente, na geração de bolhas especulativas nos mercados acionário e imobiliário. Essas bolhas também foram sustentadas por aplicações de não-residentes (investimentos de portfólio estrangeiros) nesses mercados. Vale destacar que esse ciclo esteve diretamente vinculado à liberalização financeira interna, implementada pelos países da região a

\footnotetext{
${ }^{24}$ Interpretações semelhantes são encontradas em Akyüz (1998), Dymsky (1998), Belluzzo (1998) e Unctad (1998).

${ }^{25}$ É importante mencionar que esse ciclo creditício se superpôs a um ciclo de negócios, associado à dinâmica regional de crescimento do Sudeste Asiático. Sobre essa dinâmica e a dimensão produtiva da crise, ver Medeiros (1998), Cunha (1998) e Miranda (1998)

${ }^{26}$ Vários países da região elevaram as taxas de juros a partir de 1993 com o objetivo de conter a deterioração das contas externas. Esta deterioração estava associarla a problemas no modelo de crescimento dos NICs de segunda geração (Tailândia, Indonésia, Malásiae Filipinas), com destaque para a desaceleração do crescimento das exportações Nesse contexto, a desvalorização do yuan de 33\% em relação do dólar no $1^{\circ}$ trimestre de 1994 e a dinâmica exportadora da China contribuíram para deteriorar ainda mais o déficit em conta corrente das economias asiáticas. Esta deterioração somada às necessidade de amortizar ou rolar o passivo externo, resultaram em necessidades crescentes de captação de recursos no exterior (Cunha, 1998 e Miranda, 1998).
} 
partir do final dos anos 80. Num ambiente de liberalização financeira, dois fatores reforçaram o comportamento pró-cíclico dos bancos na concessão dos empréstimos. Por um lado, a redução dos requerimentos de reserva aumentou a capacidade de empréstimo, permitindo a acomodação de uma maior demanda de crédito. Por outro lado, a entrada de novos competidores induziu os bancos a se engajarem em atividades de maiores riscos e contribuiu para $o$ aumento dos créditos de má qualidade ${ }^{27}$.

Na teoria de Minsky, a passagem de uma situação de fragilidade para uma de instabilidade financeira estava associada a mudanças na política monetária interna (como um choque de juros) ou à reversão do estado de convenções que sustentava as expectativas otimistas dos empresários. Mas, no caso das economias asiáticas, dado o contexto de abertura financeira $e$ absorção de recursos externos pelas empresas e bancos domésticos, a instabilidade financeira foi causada pela reversão dos fluxos de capitais externos; e pela crise cambial que acompanhou essa reversão. Conseqüentemente, a fragilidade financeira dos bancos e das empresas, com dívidas em moeda estrangeira, ampliou-se, resultando na eclosão (ou no agravamento) de crises financeiras domésticas ${ }^{28}$. A resposta de política, que seguiu os recomendações do FMI, contribui para agravar a crise. A elevação da taxa de juros interna aumentou o risco de inadimplência das empresas e deteriorou a situação financeira dos bancos, ambos já fragilizados pela desvalorização cambial. A política fiscal restritiva reduziu ainda mais a demanda doméstica, dificultando o aumento das receitas e precipitando o processo de liquidação de ativos e, assim, de debt-deflation. O processo de deflação de dívidas teria sido deflagrado porque os fatores que, segundo Minsky, explicavam porque a grande depressão "can't happen again" o "Big Government" e o "Big Bank" - estavam ausentes no caso dos

\footnotetext{
${ }^{27}$ Esses problemas não são exclusivos dos países periféricos. A liberalização financeira também foi um dos determinantes das crises bancárias recentes em alguns paises centrais, como Suécia e Noruega. No entanto, podem-se manifestar com maior intensidade nesses países, que não possuem sistemas financeiros robustos, ancorados no mercado de crédito ou de capitais

${ }^{28}$ Vale mencionar que o impacto disruptivo da desvalorização e da instabilidade cambial sobre as economias do sudeste asiático não decorreu apenas do elevado nível de endividamento externo, mas também do modelo de crescimento regional, caracterizado por uma forte concentração do comércio exterior dos países dentro da região. A estabilidade dos custos e preços relativos - ou seja, da taxa de câmbio - desempenhava um papel fundamental nesse modelo (Kregel, 1998b). No entanto, como destaca Miranda (1998), a manutenção dos regimes de câmbio administrado ${ }^{4}$ não garantiria a sustentabilidade desse modelo. A acentuada volatilidade da taxa de câmbio iene/dólar foi um dos fatores responsáveis pela progressiva fragilidade financeira das economias do sudeste asiático, dadas as características da estrutura de passivo dos países, denominadas tanto em iene como em dólar. Se o dólar se valorizava, os efeitos positivos sobre a competitividade das exportações asiáticas - concentradas em commodities internacionais cotadas nesse moeda - eram em grande parte anulados pelo aumento do preço das máquinas e equipamentos importados do Japão, em média, $85 \%$ do total. Dessa forma, tanto da valorização do iene quanto do dólar atingiam de forma perversa os termos de troca dos páises do sudeste asiático. Assim, para esse autor as raízes da crise devem ser buscadas na inexistência de um padrão monetário internacional estável.
} 
países asiáticos. Por um lado, o gasto público não pode funcionar como fonte adicional de demanda agregada na fase descendente do ciclo econômico, evitando uma queda abrupta das receitas correntes das empresas e, assim, a liquidação em massa dos ativos. Por outro lado, como a maior parte dos ciclo creditício interno foi alavancado por empréstimos externos, o raio de manobra que os bancos centrais locais possuíam para atuarem como emprestadores de última instância era muito pequeno - equivalente ao volume de reservas internacionais. Assim, os responsáveis de fato pela crise não foram as falhas nos mecanismos de supervisão e regulamentação do sistema financeiro (IMF, 1998 a e b) ou o crony capitalism (Krugman, 1998), mas a inserção desses países no ambiente de globalização financeira. A abertura financeira e a liberalização financeira permitiram a absorção excessiva dos fluxos de capitais em busca de valorização, e a expansão excessiva dos empréstimos internos, que foi acompanhada por uma bolha especulativa no mercado de ativos. Assim, pode-se dizer que se reproduziu nesses países um ciclo econômico dominado pela evolução dos preços dos ativos e alimentado pela expansão do crédito bancário (que também foi observado em vários países centrais nos anos 80; ver Aglieta, 1995, Freitas, 1997a), mas cujo impulso inicial e fundamental foi o ingresso de capitais externos, em busca de valorização na esfera financeira. $\mathrm{O}$ aperfeiçoamento dos mecanismos de regulamentação e supervisão bancárias podem contribuir para atenuar a assunção excessiva de riscos, mas não é suficiente para conter a lógica de valorização do capital dos bancos, que procuram constantemente evadir os limites impostos pelas autoridades monetárias. As chamadas assimetrias informacionais - seleção adversa e risco moral - não são eliminadas pela mera correção das falhas institucionais, como supõe a teoria convencional, pois são consequiências da própria lógica da concorrência bancária.

\section{Considerações finais: Algumas implicações para a América Latina e a Ásia.}

Na década de 80, muitos países do Pacífico Asiático pareciam estar destinados a superar a condição de "em desenvolvimento" 29 . Constatava-se uma participação crescente desses países no comércio internacional, especialmente nos setores mais modernos, intensivos em tecnologia ${ }^{30}$; taxas de crescimento duas a três vezes superiores à média mundial (tabela 1, em anexo); estabi-

${ }^{20}$ O FMI já classifica há alguns anos Coréia do Sul, Hong Kong, Cingapura, Taiwan, no grupo das economias avançadas, para efeito da apresentação dos seus dados estatísticos (ver, por exemplo, IMF, 1998a e b, anexos estratísticos). No começo dos anos 90, a Coréia do Sul passou a ser um país membro da ODCE.

${ }^{30}$ Segundo a UNCTAD (1998, p. 31), em 1996, a região Ásia-Oceania respondeu por $25.6 \%$ das exportações mundiais, dos quais $8 \%$ corresponderam à participação japonesa. Destaca-se a participação em manufaturas $(28.8 \%$ do total mundial), especialmente na automobilística (19.8\% do mundo, porém com o Japão exportando $15.9 \%) \mathrm{e}$ equipamentos de escritónio e telecomunicações (49.9\% do mundo, dos quais 15\% do Japão). Em 1961-63, Coréia do Sul, Taiwan, Hong Kong e Cingapura, participavam com $2 \%$ do total mundial das exportações de produtos manufaturados. Esse número chegou a $9 \%$ no início dos anos 90 (UNCTAD, 1996) 
lidade macroeconômica (tabela 2); e significativa melhoria nos indicadores sociais $^{31}$. Nem mesmo a crise da dívida no início dos anos 80 foi capaz de refrear seu dinamismo. Na América Latina, ao contrário, a década de 80 significou uma reafirmação do "subdesenvolvimento". A crise da dívida e, por decorrência, a transferência líquida de recursos para o resto do mundo ${ }^{32}$, a crescente instabilidade econômica e o crescimento medíocre (tabelas 1 e 2), tornaram a realidade local cada vez mais distante do ideal dos anos 50: o de integrar as populações excluídas dos circuitos mercantis de uma sociedade de consumo de massa, a partir do controle endógeno das variáveis poupança e investimento.

O desempenho asiático passou a ser considerado como referência para os demais países. Em decorrência, o debate em torno das causas do "milagre asiático", dividiu acadêmicos e instituições multilaterais interessados na questão do desenvolvimento econômico ${ }^{33}$. Alguns colocavam mais ênfase nos mecanismos de mercado e na estabilidade macroeconômica alcançada naqueles países: a forte integração aos mercados externos - industrialização pela via da promoção de exportações - e o reduzido grau de intervenção do Estado na economia explicariam o "milagre". Outros procuraram mostrar que a política teve um papel central na construção de vantagens comparativas dinâmicas. Vale dizer, a despeito das desvantagens comparativas estáticas, o planejamento econômico (políticas industriais e comerciais ativas, crédito direcionado, controle do investimento estrangeiro, etc.) foi capaz de acelerar a modernização produtiva em uma direção em que os preços correntes de mercado apontavam como sendo relativamente desfavorável. Apontava-se para a existência de um padrão de desenvolvimento alternativo ao modelo liberal, no qual o papel do Estado na condução do processo de acumulação exerceria as funções de manter a estabilidade macroeconômica, prover infraestrutura física (capital físico e humano, mas somente em atividades em que há comprovadas falhas de mercado) e legal (instituições que estabelecessem as "regras do jogo") ${ }^{34}$. Uma terceira linha de argumentação enfatizava que o crescimento asiático seria o resultado de um processo de rápido acúmulo de capital físico e humano, cujas fontes - incorporação das populações rurais, montagem de novos setores industriais e urbanização - estariam por se esgotar. Se não houvesse uma significativa melhora na eficiência daquelas economias - o que significaria uma

\footnotetext{
31 Ver Cunha (1997). É importante ressaltar os efeitos deletérios da crise atual. Estimativas do FMI (IMF, 1998b) apontam para um significativo aumento da pobreza (quase dobrando o número de pobres sobre o total da população na Indonésia, Coréia e Tailândia), dada a queda forte da renda, o aumento da inflação e do desemprego - que, entre 1997 e 1998, passaria de $5 \%$ para $15 \%$ na Indonésia, de $2 \%$ para $7.5 \%$ na Coréia e de 2 para $6 \%$ na Indonésia.

32 Entre 1982 e 1990, houve uma transferência líquida negativa equivalente a $3.2 \%$ do PIB da América Latina e Caribe (CEPAL, 1996, p. 23).

${ }^{33}$ Para uma revisão crítica do debate ver Cunha (1997 e 1998).

${ }^{34}$ Em termos concretos isso significava a opção pela montagem acelerada de setores industriais intensivos em capital e tecnologia, recursos relativamente escassos nos paises em desenvolvimento . Na Coréia, os Planos Qüinqüenais da década de 70 exemplificam este ponto (CUNHA, 1997).
} 
ampliação mais do que proporcional da produtividade total dos fatores - seria de se esperar taxas de crescimento da renda cada vez menores ${ }^{35}$.

A recente crise financeira serviu de base para o reforço de argumentos críticos ao padrão de desenvolvimento asiático. A função disciplinadora dos mercados competitivos teria sido comprometida pelo "capitalismo de compadres", no qual o Estado dava benefícios a agentes privados, gerando comportamentos de alto risco (IMF,1998a, 1998b). Caem por terra as virtudes e emerge a constatação quase unânime no mainstream: mais cedo ou mais tarde, a intervenção política sobre os mercados acaba gerando graves problemas alocativos e, em última instância, crises econômicas. Rapidamente, os mais bem-sucedidos países em desenvolvimento voltaram à vala comum. A periferia capitalista passou a ser igualada do ponto de vista da imprudência na gestão macroeconômica e da fragilidade de suas instituições.

Nos anos 90, a liberalização financeira e comercial e a crescente instabilidade econômica mostraram-se como duas faces de uma mesma moeda. Para as economias capitalistas periféricas, a agenda de reformas estruturais que emerge da visão convencional procura enfatizar: (i) a necessidade de rever as práticas de supervisão dos sistemas financeiros locais e de fornecimento das informações contábeis de instituições privadas financeiras e não-financeiras; (ii) o aprofundamento e/ou manutenção da liberalização financeira interna e externa e da abertura comercial; (iii) e o equacionamento das fragilidades nos fundamentals, mediante o controle das contas fiscais e externas e da estabilidade monetário-cambial (IMF, 1998a e 1998b). Estas medidas, como procurou-se argumentar anteriormente, são uma decorrência lógica da visão convencional sobre as crises financeiras. E, mais do que isso, decorrem da percepção de que os países em desenvolvimento apresentariam certas especificidades: a fragilidade de suas instituições e fundamentals. O bom senso parece indicar que estes são fatores de efetiva importância. Porém duas questões merecem uma maior reflexão: (i) esta agenda é suficiente para a estabilidade e a retomada do desenvolvimento?; (ii) e, mais do que isso, elas ampliam ou restrigem a adoção de estratégias de aceleração do desenvolvimento?

Acredita-se que a agenda convencional é insuficiente e restritiva. Insuficiente, na medida em que a avaliação das especificidades dos "países em desenvolvimento" é parcial. Ela desconsidera e/ou minimiza a consideração de que as recorrentes crises cambiais e bancárias, associadas a movimentos prévios de sobreendividamento interno e externo, refletem: (i) uma posição subordinada na divisão internacional do trabalho, na qual as economias periféricas tendem a especializar suas estruturas produtivas e, em decorrência, comerciais, em setores intensivos em trabalho e recursos naturais, o que pressiona, negativamente, seus balanços comerciais, especialmente quando há quedas significativas no preço internacional das commodities e/ou processos de valorização

\footnotetext{
${ }^{35}$ A idéia de que o "milagre asiático" não passaria de um mito foi colocada no centro do debate recente por Krugman, em 1994 (CUNHA, 1997). Para uma resenha da literatura convencional que procura estimar as fontes do crescimento asiático, ver IMF (1998b).
} 
cambial das moedas locais ${ }^{36}$; (ii) problema que se agrava com o protecionismo dos países industrializados; (iii) e a dependência dos fluxos de capitais externos para financiar o excedente entre a absorção e a poupança doméstica. Ou seja, a agenda convencional ignora os problemas centrais da agenda desenvolvimentista das economias capitalistas periféricas destacados pelo pensamento estruturalista latino-americano: (i) a impossibilidade de absorver, desenvolver e gerar tecnologias que estivessem ao par com a fronteira tecno-produtiva determinada nos países centrais; (ii) a insuficiência de financiamento interno e externo; (iii) e a incapacidade de implementar estratégias de desenvolvimento a partir de determinantes políticos e sociais internos (PREBISCH, 1981).

É uma agenda restritiva, pois ela busca colocar obstáculos à adoção de estratégias diferenciadas de desenvolvimento que, necessariamente, estão associadas à possibilidade de controle do crédito - interno e externo - e à adoção de políticas industriais e comerciais ativas. Pressupõe, portanto, que não há espaço para o estabelecimento da diversidade institucional. Por decorrência lógica, ao se perceber a especificidade da periferia somente na questão da instabilidade cambial e na fragilidade do sistema bancário e da regulamentação do sistema financeiro, geram-se propostas do tipo: (i) adoção de sistemas de conversibilidade cambial; (ii) ampliação da internacionalização do sistema bancário e financeiro; (iii) limitações na existência de propriedade cruzada entre empresas não-financeiras, e entre estas e empresas financeiras; (iv) restrições em padrões de financiamento baseadós no endividamento junto ao sistema bancário (relações entre dívida e ativos), que normalmente são associados à participação cruzada entre bancos e empresas industriais; entre outros.

Wade \& Veneroso (1998) argumentam que a flexibilidade cambial, em conjunto com políticas ativas de crédito e estímulo à indústria infante, e um padrão de financiamento marcado pelo elevado endividamento e participações cruzadas entre bancos e indústria, marcou a experiência dos países asiáticos mais bem-sucedidos em seus períodos de modernização acelerada. Ou seja, os países que mais avançaram no processo de catching up com as nações industrializadas adotaram instituições e políticas marcadamente distintas dos padrões anglo-saxônicos ${ }^{37}$. Guardadas suas especificidades, no Japão, na Coréia do Sul e em Taiwan, os determinantes internos da consolidação da segurança nacional em um ambiente externo conflitivo - localizavam-se na fronteira

\footnotetext{
${ }^{36}$ A UNCTAD (1996) destaca que os países em desenvolvimento do Pacífico Asiático, apesar do seu crescimento acelerado, mostravam uma forte dificuldade em promover um upgrading de sua estrutura produtiva, pois: (i) permaneceria uma forte dependência na importação de componentes de maior conteúdo tecnológico, (ii) e haveria uma pressão competitiva, "por baixo" da China, nos setores intensivos em trabalho, e "por cima" setores intensivos em tecnologia - do Japão. Coréia do Sul, Taiwan, Hong Kong e Cingapura, apresentaram uma forte convergência de suas estruturas industriais com relação aos países industrializados (G7) ampliando a participação dos setores de média e alta tecnologia no valor adicionado da indústria. Por este prisma, as principais economias latinas foram incapazes de convergir para esse padrão (tabela 3 , em anexo e CUNHA, 1998). Com relação aos impactos negativos de variações nos preços das commodities e do câmbio ver UNCTAD (1998).

${ }^{37}$ Pode-se encaixar aqui países como Alemanha e Japão, em seu perỉodo de reconstrução e modernização nas décadas de 50 e 60. Mais recentemente países como Coréia do Sul e Taiwan e, também, Brasil, Índia e China, destacaram-se neste sentido
} 
entre o ocidente capitalista e o oriente comunista - geraram a priorização da industrialização acelerada, com um esforço consciente de endogenização das capacidades tecnológicas e controle da poupança (CUNHA, 1997). A viabilidade deste padrão era dada por um rígido controle da poupança e, portanto, do sistema financeiro, e pela canalização dos recursos financeiros, internos e externos para o setor produtivo.

Com a liberalização financeira e o abandono das política de coordenação das inversões e direcionamento do crédito, criou-se espaço para o excesso de investimentos, o sobreendividamento externo e posturas fortemente especulativas. Invertendo a leitura convencional, teria sido o abandono das políticas de desenvolvimento que gerou as condições para a crise. Esse abandono somado à inserção das economias asiáticas na globalização financeira recolou, para os países asiáticos, o problema da vulnerabilidade externa (que refere-se à vulnerabilidade das economias nacionais às mudanças na dinâmica econômica e financeira internacional). No caso dos países latino-americanos, a vulnerabilidade externa sempre foi um elemento estrutural, sendo que sua principal forma de manifestação foram as recorrentes crises cambiais, que atingiram esses países em vários momentos da história. Contudo a vulnerabilidade apresentou diferenças qualitativas, em função dos distintos padrões de inserção externa desses países ao longo de sua evolução histórica e, em alguns momentos, manteve-se latente por vários anos, como nos ciclos de endividamento externos dos anos 70 e das primeira metade dos 90 . Assim, a crise recente das economias asiáticas suscita a seguinte reflexão: será que é possível a superação definitiva da vulnerabilidade externa, ou esse elemento constitui uma característica estrutural das economias periféricas e dependentes?

A experiência asiática deve ser avaliada em uma perspectiva dinâmica. Não se espera uma volta aos parâmetros institucionais que vigoraram até meados dos anos $70 \mathrm{e}$ que davam um maior grau de liberdade ao estabelecimento de políticas nacional-desenvolvimentistas. Porém deve-serefletir cuidadosamente sobre atéque ponto o abandonode certa flexibilidade institucional é adequada para todos os países em desenvolvimento. $\mathrm{Na}$ agenda convencional, acrise torna-se uma justificativa forte para reformas institucionais que limitamo poder de controle sobre o crédito e o investimento. Istoé uma decorrência direta, conforme procurouse argumentar, dos próprios limites daquela visão sobre as crises financeiras.

\section{Referências bibliográficas}

AGL.IETTA, M. (1995) Macroéconomie financière, Paris: Édition La Découverte, $1^{\text {a }}$ edição.

AKYÜZ, Y.(1998) The East Asian Financial Crisis: Back to the Future. Geneve: UNCTAD (mimeo).

BELLUZZO, Luiz G. de Mello (1998) "Notas sobre a crise da Ásia". Praga, estudos marxistas $n^{\circ}$ 5. São Paulo: Editora Hucitec.

BIS (1998). 68 $^{\text {th }}$ Annual Report. Basle: Bank for International Settlements.

BOISSIEU, C. (1994). Le destin de la bulle financière. Futuribles, nov., Paris. 
CEPAL (1996). Quince Años de Desempeño Económico. Santiago do Chile: Naciones Unidas. Comisión Económica Para América Latina y Caribe.

CHESNAIS, F(1996)، A Mundialização do Capital. São Paulo: Xamã.

CORsetTI, G., PESSETI, P., ROUBINI, N. (1998). Paper 'Tigers? A Preliminary Assessment of the Asian Crisis. NBER-Bank of Portugal Seminar on Macroeconomics (ISOM), Lisboa, 14 e 15 de junho (mimeo).

CUNHA, André Moreira (1997). O Milagre Asiático: Avanços e Recuos na Explicação Ortodoxa. Anais do II Encontro Nacional de Economia Política. São Paulo: PUC-SP.

CUNHA, André Moreira (1998). O Pacífico Asiático: Da Integração Econômica dos Anos 80 e 90 à Crise Financeira. Anais do III Encontro Nacional de Economia Política. Niterói, RJ: UFF.

DEMIRGÜÇ-KUNT, Ash, DETRAGIACHE, Enrica (1998). Financial Liberalization and Financial Fragility. IMF Working Paper, 98/83, june.

EICHENGREEN, Barry (1996).Globalizing Capital: A History of The International Monetary Sistem. Princeton: Princeton University Press.

FERREIRA, Carlos Kawall \& FREITAS, Maria Cristina (1995) Os bancos de desenvolvimento frente ao mercado de capitais e aos novos intermediários financeiros, Trabalho Vencedor do XVI Concurso Latinoamericano sobre Bancos de Fomento 1994/95 realizado pela ALIDE - Associación Latinoamericana de Instituciones Financieras de Desarollo.

FREITAS, Maria C. P (1997a) Concurrence Bancaire, Spéculation et Instabilité Financière: une lecture hétérodoxe de l'évolution récente du système financier international. Villetaneuse: Université de Paris XIII/U.F.R. de Sciences Economiques et Gestion (Thèse de Doctorat en Sciences Economiques).

FREITAS, Maria C. P. (1997b). A Natureza Particular da Concorrência Bancária e Seus Efeitos Sobre a Estabilidade Financeira. Economia e Sociedade $n^{\circ} 8$, Instituto de Economia da Unicamp, Campinas.

IMF(1997).World Economic Outlook. Washington DC: International Monetary Fund, october

IMF (1998a). World Economic Outlook. Washington DC: International Monetary Fund, may.

IMF(1998b). World Economic Outlook. Washington DC: International Monetary Fund, october.

KAMINSKY, G., LIZONDO, S., REINHART, C. (1998). Leading Indicators of Currency Crisis. Washington DC: IMF (mimeo).

KEYNES, J. M.(1936), Teoria Geral do Emprego, do Juro e da Moeda, São Paulo: Nova Cultural, 1985, $2^{\text {a }}$ edição.

KREGEL, J. A (1998a). Yes, “It' Did Happen Again - A Minsky Crisis Happened in Asia. Presented at the Eighth Annual Hyman P. Minsky Conference on Financial Structurem april 23-24. Working Paper n. 234, The Jeromy Levy Economic Institute (http://www.levy.org) KREGEL, J. A.(1998b) East Asia is not Mexico: the difference between balance of payments crises and debt deflations. Geneve: UNCTAD, mimeo.

KRUGMAN, Paul. (1998). What Happened to Asia? (mimeo).

KRUGMAN, Paul. (1997). Currency Crises. (Erro! Indicador não definido. Palestra proferida no National Bureau of Economic Research, outubro.

KRUGMAN, Paul (1991). Financial Crisis in the International Economy. In FELDSTEIN, Martin (1991). The Risk of Economic Crisis. Chicago: The University of Chicago Press. 
KRUGMAN, Paul (1979). A Model of Balance of Payments Crises . Journal of Money, Credit and Banking, v.11, n.3, august, p.311-325.

KINDLEBERGER, Charles P. (1978). Manias, Panics and Crashes. New York: Basic Books.

MINSKY, Hyman P. (1991). The Financial Instability Hypothesis: a Clarification. . In FELDSTEIN, Martin (1991). The Risk of Economic Crisis. Chicago: The University of Chicago Press.

MIRANDA, José C.(1998). A Dinâmica Financeira da Crise Asiática. Revista Política

Externa, vol. 6, $n^{\circ}$ 4. Rio de Janeiro: Paz e Terra, pp. 130-150.

MISHKIN, Frederic S. (1998). International Capital Movements, Financial

Volatility and Financial Instability. NBER Working Paper, 6390. Cambridge, Massachusetts: no National Bureau of Economic Research.

MISHKIN, Frederic S. (1996). Understanding Financial Crises: A Developing Country Perspective. NBER Working Paper, 5600. Cambridge, Massachusetts: no National Bureau of Economic Research.

MISHKIN, Frederic S. (1992). Anatomy of a Financial Crisis. Journal of Evolutionary Economics, n.2, p.115-130.

OBSTFELD, Maurice (1996). Models Of Currency Crises With Self-Fulfilling Features. European Economic Review, n.40, p. 1037-1047.

PRATES, Daniela M. (1997). Abertura Financeira e Vulnerabilidade Externa: a Economia Brasileira na Década de 90. Campinas, (Dissertação de Mestrado), Instituto de Economia - Universidade Estadual de Campinas, agosto.

PREBISCH, Raúl (1981). Capitalismo Periferico: Crisis e Transformacion. México:

Fondo de Cultura Economica

UNIDO (1997). Financing Industrial Development. Industrial Development - Global

Report 1997. Oxford: Oxford University Press.

UNITED NATIONS (1998). Trade and Development Report, 1998. Genebra: United

Nations Conference on Trade and Development - United Nations.

WADE, Robert, VENEROSO, Frank (1998). The Asian Crises: The High Debt Model

Versus The Wall Street-Tresuary-IMF Complex. New Left Review, n.228, p. 3-

23, march/april. London: New Left Review Ltd.

Tabela 1: Variação Anual do PIB Real em Regiões Selecionadas (\% - variação anual)

\begin{tabular}{|l|r|r|r|r|r|r|r|r|r|r|r|}
\hline & $\mathbf{1 9 8 0 - 8 9}$ & $\mathbf{1 9 9 0}$ & $\mathbf{1 9 9 1}$ & $\mathbf{1 9 9 2}$ & $\mathbf{1 9 9 3}$ & $\mathbf{1 9 9 4}$ & $\mathbf{1 9 9 5}$ & $\mathbf{1 9 9 6}$ & $\mathbf{1 9 9 7}$ & $\mathbf{1 9 9 8}$ & $\mathbf{1 9 9 9}$ \\
\hline Mundo & 3,4 & 2,7 & 1,8 & 2,5 & 2,6 & 3,9 & 3,7 & 4,2 & 4,1 & 2 & 2,5 \\
\hline G7 $^{1}$ & 2,9 & 2,7 & 1,2 & 1,9 & 1,2 & 3,2 & 2,5 & 3 & 3,1 & 2 & 1,9 \\
\hline NICs Asiáticos $^{2}$ & 7,8 & 7,3 & 7,9 & 5,8 & 6,3 & 7,6 & 7,3 & 6,3 & 6 & $-2,9$ & 0,7 \\
\hline Ásia & 7 & 5,6 & 6,6 & 9,5 & 9,3 & 9,6 & 9 & 8,2 & 6,6 & 1,8 & 3,9 \\
\hline AL & 2,2 & 1 & 3,8 & 3,3 & 3,9 & 5,2 & 1,2 & 3,5 & 5,1 & 2,8 & 2,7 \\
\hline
\end{tabular}

Fonte: IMF (1998a, Apêndice Estatístico). Os dados para 1998e 1999 são projeções. (1)EUA, Alemanha, Japão, França, Itália, Grã-Bretanha e Canadá. (2) Coréia do Sul, Taiwan, Hong Kong e Cingapura. Nota: para um detalhamento dos países que pertencem a cada região e detalhes metodológicos, ver a fonte. 
Tabela 2: Indicadores Macroeconômicos em Países Selecionados, 1975-1996

\begin{tabular}{|c|c|c|c|c|c|c|c|c|}
\hline & \multicolumn{2}{|c|}{$\begin{array}{c}\text { Crescimento (\% ao } \\
\text { ano) }\end{array}$} & \multicolumn{2}{|c|}{ Inflacão (\% ao ano) } & \multicolumn{2}{|c|}{$\begin{array}{c}\text { Balanço Fiscal (\% } \\
\text { PIB)** }\end{array}$} & \multicolumn{2}{|c|}{$\begin{array}{c}\text { Conta } \\
\text { Corrente/PIB }(\%)^{*}\end{array}$} \\
\hline & $\begin{array}{l}1975- \\
1985\end{array}$ & $\begin{array}{l}1986- \\
1996\end{array}$ & $\begin{array}{l}1975- \\
1985\end{array}$ & $\begin{array}{l}1986- \\
1996\end{array}$ & $1975-1985$ & $\begin{array}{l}1986- \\
1996\end{array}$ & $\begin{array}{l}1975- \\
1985\end{array}$ & $\begin{array}{l}1986- \\
1996 \\
\end{array}$ \\
\hline China & 7,9 & 9,9 & 2,7 & 11,6 & -1 & $-1,9$ & 0,4 & 0,4 \\
\hline $\begin{array}{l}\text { Hong } \\
\text { Kong }\end{array}$ & 8,2 & 6,3 & 8,2 & 8 & 1,1 & 2,1 & 3 & 5,6 \\
\hline Indonésia & 5,7 & 7,4 & 13,4 & 8,2 & 0,3 & $-0,5$ & -2 & $-2,8$ \\
\hline Coréia & 7,6 & 8,6 & 13,5 & 5,7 & $-2,2$ & $-0,1$ & $-3,7$ & 0,9 \\
\hline Malásia & 6,3 & 7,8 & 4,8 & 2,6 & $-5,3$ & $-2,4$ & $-3,2$ & $-2,6$ \\
\hline Filipinas & 2,9 & 3,7 & 15,6 & 8,9 & -2 & $-2,3$ & $-5,1$ & $-2,5$ \\
\hline Cingapura & 7,2 & 8,4 & 3,4 & 1,9 & 1,9 & 9,1 & $-7,2$ & 9,5 \\
\hline Taiwan & 8,3 & 7,7 & 6,3 & 3 & 0,3 & $-0,5$ & 4,3 & 7,8 \\
\hline Tailândia & 6,6 & 9,1 & 7,2 & 4,5 & $-3,7$ & 2,1 & $-5,5$ & $-4,9$ \\
\hline Brasil & 4,1 & 2,6 & 101,2 & 983,1 & n.d. & $-1,3$ & $-3,6$ & $-0,6$ \\
\hline Chile & 2,2 & 7,7 & 81 & 15,8 & 0,9 & 2,6 & $-6,5$ & $-3,1$ \\
\hline Índia & 5 & 5,9 & 6,7 & 9,2 & $-6,8$ & $-7,4$ & $-0,7$ & -2 \\
\hline México & 4,7 & 2 & 39,5 & 45,7 & $-5,2$ & -4 & $-2,3$ & $-2,8$ \\
\hline
\end{tabular}

Fonte: IMF (1998b, parte III, p. 32). * Governo Central ** Para Hong Kong, dados da balança de bens e serviços.

Tabela 3: Estrutura Industrial em Regiões Selecionadas, 1980-1995.

\begin{tabular}{|l|c|c|c|c|c|c|c|c|}
\hline \multirow{2}{*}{} & \multicolumn{2}{|c|}{ G7 } & \multicolumn{2}{c|}{$\begin{array}{c}\text { NICs } \\
\text { Asiáticos }\end{array}$} & \multicolumn{2}{c|}{$\begin{array}{c}\text { América } \\
\text { Latina }^{2}\end{array}$} & \multicolumn{2}{c|}{ Brasil } \\
\cline { 2 - 8 } & 1980 & 1995 & 1980 & 1995 & 1980 & 1995 & 1980 & 1995 \\
\hline Setores de Baixa Tecnologia & $53,43 \%$ & $48,52 \%$ & $62,02 \%$ & $49,39 \%$ & $71,10 \%$ & $68,79 \%$ & $59,68 \%$ & $53,70 \%$ \\
\hline Setores de Média Tecnologia & $22,90 \%$ & $26,59 \%$ & $19,43 \%$ & $23,07 \%$ & $19,46 \%$ & $23,46 \%$ & $21,66 \%$ & $27,75 \%$ \\
\hline Setores de Alta Tecnologia & $22,38 \%$ & $23,45 \%$ & $16,98 \%$ & $27,40 \%$ & $8,37 \%$ & $6,85 \%$ & $16,96 \%$ & $17,06 \%$ \\
\hline
\end{tabular}

Fonte: Unido 1997. Classificação setorial da UNIO-ISIC. Elaboração dos autores. (1) Coréia do Sul, Taiwan, Cingapura e Hong Kong. (2) Argentina, Chile, Colômbia, México e Venezuela. 
Tabela 4: Fxportações Mundiais, por regiões e países selecionados, 1980-1997.

\begin{tabular}{|c|c|c|c|c|c|c|c|c|}
\hline & \multicolumn{4}{|c|}{ Valor (US\$ bilhões) } & \multicolumn{4}{|c|}{ Participação (\%) } \\
\hline & 1980 & 1985 & 1990 & 1997 & 1980 & 1985 & 1990 & 1997 \\
\hline Mundo & 2034,00 & 1950,00 & 3438,00 & 5464,00 & $100,00 \%$ & $100,00 \%$ & $100,00 \%$ & 100,00 \\
\hline $\begin{array}{l}\text { América do } \\
\text { Norte }\end{array}$ & 293,56 & 309,98 & 521,78 & 903,49 & $14,43 \%$ & $15,90 \%$ & $15,18 \%$ & 16,54 \\
\hline Canadá & 67,73 & 90,95 & 127,63 & 214,42 & $3,33 \%$ & $4,66 \%$ & $3,71 \%$ & $3,92 \%$ \\
\hline EUA & 225,57 & 218,82 & 393,59 & 688,70 & $11,09 \%$ & $11,22 \%$ & $11,45 \%$ & $12,60 \%$ \\
\hline $\begin{array}{l}\text { Europa } \\
\text { Ocidental }\end{array}$ & 815.54 & 776.34 & 1637,12 & 2276,47 & $40,10 \%$ & $39,81 \%$ & $47,62 \%$ & 41,66 \\
\hline França & 116,03 & 101,67 & 216,59 & 289,55 & $5,70 \%$ & $5,21 \%$ & $6,30 \%$ & $5,30 \%$ \\
\hline Alemanha* & 192,86 & 183,93 & 421,10 & 511,68 & $9,48 \%$ & $9,43 \%$ & $12,25 \%$ & $9,36 \%$ \\
\hline Itália & 78,10 & 76,72 & 170,30 & 238,22 & $3,84 \%$ & $3,93 \%$ & $4,95 \%$ & $4,36 \%$ \\
\hline Reino Unido & 110,13 & 101,25 & 185,17 & 281,56 & $5,41 \%$ & $5,19 \%$ & $5,39 \%$ & $5,15 \%$ \\
\hline Ásia & 323,60 & 416,40 & 792,40 & 1539,60 & $15,91 \%$ & $21,35 \%$ & $23,05 \%$ & 28,18 \\
\hline China & 18,19 & 27,34 & 62,09 & 182,70 & $0,89 \%$ & $1,40 \%$ & $1,81 \%$ & $3,34 \%$ \\
\hline $\begin{array}{l}\text { Hong Kong, } \\
\text { China }\end{array}$ & 20,32 & 30,08 & 82,39 & 188,20 & $1,00 \%$ & $1,54 \%$ & $2,40 \%$ & $3,44 \%$ \\
\hline Indonésia & 21,91 & 18,59 & 25,68 & 53,54 & $1,08 \%$ & $0,95 \%$ & $0,75 \%$ & $0,98 \%$ \\
\hline Japão & 130,44 & 177,16 & 287,58 & 421,02 & $6,41 \%$ & $9,09 \%$ & $8,36 \%$ & $7,71 \%$ \\
\hline $\begin{array}{l}\text { Coréia do } \\
\text { Sul }\end{array}$ & 17,51 & 30,28 & 65,02 & 136,16 & $0,86 \%$ & $1,55 \%$ & $1,89 \%$ & $2,49 \%$ \\
\hline Malásia & 12,96 & 15,44 & 29,42 & 78,45 & $0,64 \%$ & $0,79 \%$ & $0,86 \%$ & $1,44 \%$ \\
\hline Filipinas & 5,74 & 4,61 & 8,07 & 25,27 & $0,28 \%$ & $0,24 \%$ & $0,23 \%$ & $0,46 \%$ \\
\hline Cingapura & 19,38 & 22,81 & 52,75 & 125,00 & $0,95 \%$ & $1,17 \%$ & $1,53 \%$ & $2,29 \%$ \\
\hline Taiwan & 19,78 & 30,70 & 67,14 & 121,85 & $0,97 \%$ & $1,57 \%$ & $1,95 \%$ & $2,23 \%$ \\
\hline Tailândia & 6,51 & 7,12 & 23,07 & 57,39 & $0,32 \%$ & $0,37 \%$ & $0,67 \%$ & $1,05 \%$ \\
\hline $\begin{array}{l}\text { América } \\
\text { Latina }\end{array}$ & 109,60 & 108,50 & 145,60 & 278,80 & $5,39 \%$ & $5,56 \%$ & $4,24 \%$ & $5,10 \%$ \\
\hline Argentina & 8,02 & 8,40 & 12,35 & 25,52 & $0,39 \%$ & $0,43 \%$ & $0,36 \%$ & $0,47 \%$ \\
\hline Brasil & 20,13 & 25,64 & 31,41 & 52,99 & $0,99 \%$ & $1,31 \%$ & $0,91 \%$ & $0,97 \%$ \\
\hline Chile & 4,71 & 3,80 & 8,37 & 16,88 & $0,23 \%$ & $0,20 \%$ & $0,24 \%$ & $0,31 \%$ \\
\hline México & 18,12 & 27,23 & 40,98 & 110,43 & $0,89 \%$ & $1,40 \%$ & $1,19 \%$ & $2,02 \%$ \\
\hline Venezuela & 19,22 & 14,44 & 17,50 & 23,07 & $0,94 \%$ & $0,74 \%$ & $0,51 \%$ & $0,42 \%$ \\
\hline
\end{tabular}

Fonte: Organização Mundial do Comércio (http://www.wto.org)

* 1980 e 1985 referentes à extinta República Fed. da Alemanha 